\title{
Late Proterozoic-Early Paleozoic of South America - a Collisional History
}

by Victor A. Ramos

The southern portion of South America is a complex collage of cratonic blocks that were brought together along the southwestern Gondwanaland margin in late Precambrian to early Paleozoic times. An enormous amount of recent work especially in northern Argentina and Chile, reviewed here, has led to many new ideas and models for the development of this region in terms of plate interactions and orogenic cycles. (Ed.)

\section{Introduction}

The hypothesis that continental drift caused the destruction of Gondwanaland was accepted early on by many South American geologists because of the striking similarities and correlations between the Paleozoic history of South America and southern Africa (e.g. Keidel, 1917). Most tectonic studies have assumed a fixed ensialic or ensimatic origin for the orogenic belts that predated the breakup of Gondwanaland. However, increasing evidence on the distribution of mafic and ultramafic oceanic rocks, ancient magmatic ares, and the metamorphic and sedimentary sequences of these old orogenic belts suggests that a complex collage of earlier collisons and amalgamations between lithospheric plates formed Gondwanaland in Late Proterozoic to early Paleozoic times.

Many workers on the Phanerozoic Cordillera of South America have long avoided the vast and complex Precambrian problems of the continent.

Figure 1: Main cratonic blocks and allochthonous terranes of southern South America. Horizontal lines indicate the extent of the Alto Paraguay Terrane.

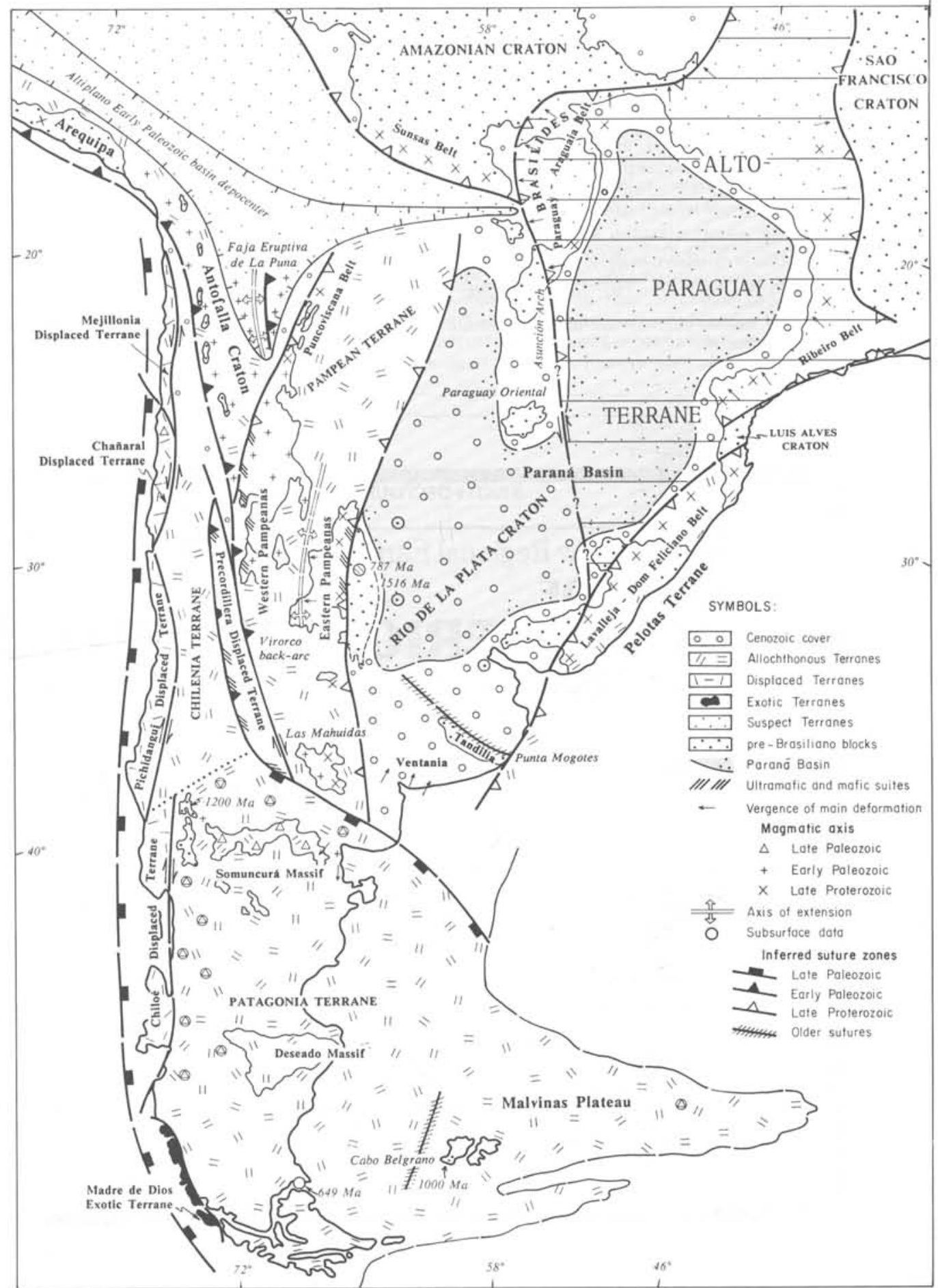


However, there is a noteworthy similarity between numerous aspects of the Meso-Cenozoic evolution of the Andes and those of the Brasilides of southwestern Brazil (Fig. 1), a Late Proterozoic to early Paleozoic mountain chain, which is the type locality of the well-known Brasiliano orogenic cycle (Almeida et al., 1976). This is especially so as regards the platform deposits, molasse sediments, metamorphic and magmatic history, and the structural development of the fold and thrust belt of the non-metamorphic Brasilides (Almeida, 1964). The analysis of this belt with its typical west-verging thrusts and underthrusts indicates that most of it was transported to the west over the Amazonian craton, typical of a peripheral setting.

Restoration of these sections indicates that large amounts of shortening postdated an Andean-type magmatic history. When these features are analyzed from a Phanerozoic Cordilleran perspective, it is evident that the evolution of these regions share more common characteristics than significant differences in terms of present tectonic models. In this regard, the pioneering efforts of Caelles (1979), who was the first to attempt to make a plate reconstruction of southern South America, should be recognized.

\section{Southern Cratons and Cratonic Fragments}

The cratonal area of southern South America is composed of several discrete segments of Archean or Early Proterozoic age (Fig. 1), which may have been allochthonous to one another. These include the Amazonian, São Francisco, Luis Alves and Rio de La Plata cratons (Cordani and Brito Neves, 1982), the margins of which underwent tectonic remobilization during the Late Proterozoic Brasiliano orogeny (Almeida et al., 1976).

These blocks define a mosaic of old continental crust amalgamated during Late Proterozoic to early Paleozoic times. Some cratons, such as the Amazonian and São Francisco, have well-defined suture boundaries marked by first order tectonic discontinuities, as depicted by Almeida and others (ibid) and Cordani and Brito Neves (ibid). Others, such as the Luis Alves block, are small fragments with a complex geological history. Large intracratonic basins, such as the Parana, that cover these Precambrian cratons obscure the correlation of the different fragments.
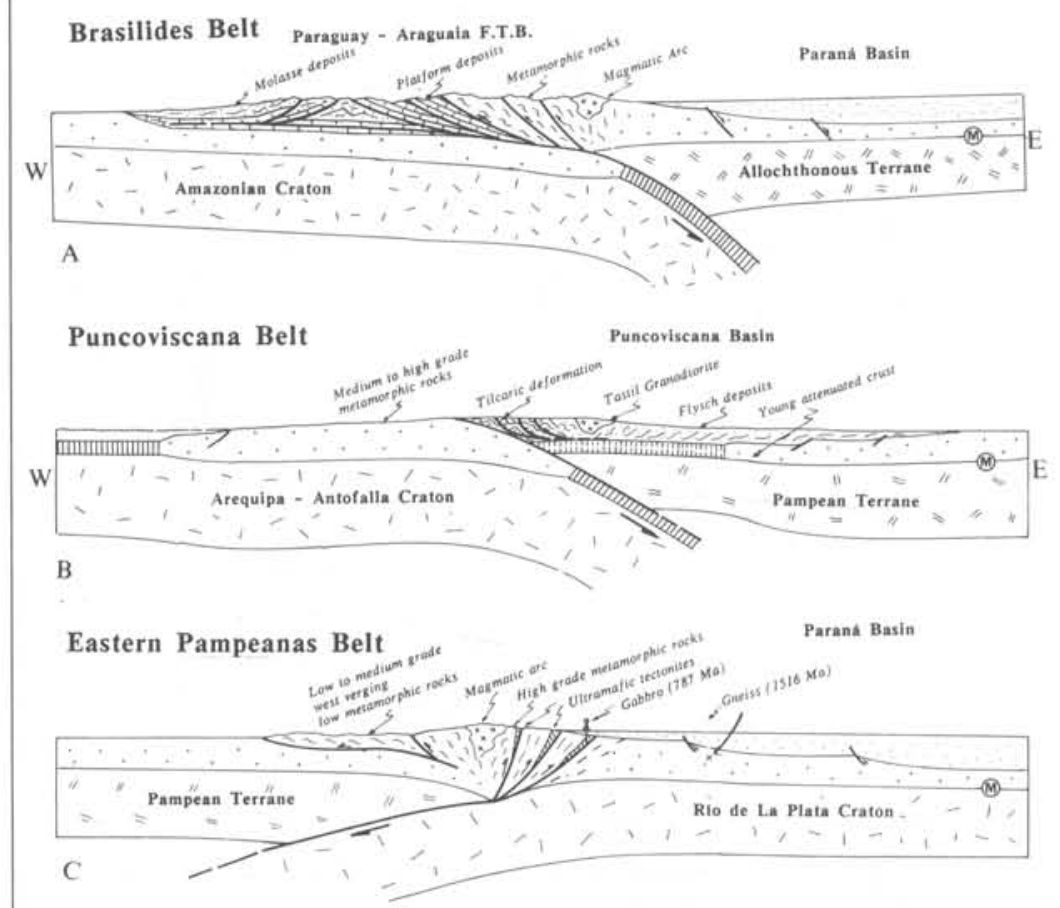

Figure 2: The Brasiliano Cycle orogens. M: Moho.
One of the major uncertainties is the extension of the Rio de La Plata craton northeast of the Paraguay Oriental exposures (Fig. 1), because Paleozoic strata of the Paraná Basin overlie a possible contact bet ween that craton and the Alto Paraguay terrane. Available subsurface data obtained from drilling during oil exploration of the Paraná Basin indicate a $\mathrm{K} / \mathrm{Ar}$ whole rock age of $1516 \mathrm{Ma}$ (Russo et al., 1979) for the basement, which suggests that a non-remobilized craton is present below part of the Paraná Basin between Paraguay and Tandilia to the south in Argentina. At the same time, seismic data indicate that the basement flanking the early Paleozoic platform cover along the eastern side of the Paraná Basin may be a southern extension of the Asuncion Arch. This same basement bounds the Eastern Sierras Pampeanas.

Some evidence suggests that the southwestern and northeastern parts of the Paraná Basin had distinct Proterozoic to early Paleozoic histories. The southwestern portion is underlain by a flat-lying Cambro-Ordovician platform facies overlying a Proterozoic sequence, and it is reasonable to assume that no major mountain chains existed during latest Proterozoic times in this region. In the northeastern part of the basin, however, the Cambro-Ordovician cover is absent, and younger early Paleozoic strata were deposited in a northwest-trending aulacogen system (Fulfaro et al., 1982). The early Paleozoic reactivation of the northwestern part of this region probably reflects a distinct Proterozoic history for this area. The boundary between these two regions could represent some kind of discontinuity in the Rio de La Plata craton, coinciding with the southern extension of the Asuncion Arch, as suggested above. A tentative boundary here is indicated in Figure 1 extending the craton boundaries recognized at both ends of the Paraná Basin by Fulfaro and his colleagues (ibid).

Some fragments of Early Proterozoic terrains are also found within and west of the Andean chain. The best known of these is the Arequipa massif (Fig. 1), which has $\mathrm{Rb} / \mathrm{Sr}$ whole rock ages as old as $1918 \pm 33 \mathrm{Ma}$ (Shackleton et al., 1979). Geochronological studies in northern Chile (Pacci et al., 1980; Damm et al., 1986) indicate that this Early Proterozoic crust also extends to the south as shown by isolated exposures at Belén, Choja, Sierra Moreno, and at Antofalla

(Fig. 1) where medium to high-grade gneisses are exposed in the westernmost Argentine Puna (Palma et al., 1986).

Preliminary data indicate the extension of Middle Proterozoic rocks into northern Patagonia, where ages of $1200 \mathrm{Ma}$ have been obtained from the gneiss complexes northwest of the Somuncura Massif (Linares et al., 1985). Farther south in the Malvinas Plateau, ages of 1100 and $980 \mathrm{Ma}$ have been obtained by Cingolani and Varela (in Anon, 1976) in the metamorphic complexes of Cabo Belgrano (Fig. 1).

Although most previous compilations suggest that all of these cratonic fragments have been together since the formation of Gondwanaland in the early Precambrian, such an hypothesis fails to explain the later Proterozoic magmatic ares, the ophiolitic belts, and the development of intercratonic mountain chains. Thus, in order to understand the Late Proterozoic evolution of the region, it is necessary to define the different types of Brasiliano orogens present.

\section{The Brasiliano Orogenic Cycle}

Late Proterozoic to earliest Paleozoic orogenic activity has been included in the Brasiliano Cycle by Almeida and others (1976). This is partially equivalent to the Panamerican cycle of 
Harrington (1975) and the Pampean orogeny of Acenolaza and Tosselli (1976). Although there are some time differences in the original definitions of these terms, when the timing of the main diastrophic episodes is compared in several regions, a wide dispersion of ages above and below the Precambrian-Cambrian boundary is found that rules out systematic differences among them. The use of the term Brasiliano Cycle is, therefore, preferred here because of its wide acceptance, though the regional validity of the other terms is also recognized.

The remobilization and reworking of pre-existing Early Proterozoic and older crust has been traditionally explained in terms of a series of mobile belts in the sense of Anhaeusser and others (1969). In their model, ensialic or ensimatic intracratonic magmatism and important metamorphic events are related to vertical accretion, which is the principal tectonic mechanism (e.g. Bernasconi 1987, Dalla Salda, 1987).

The Brasiliano orogens, show a diversity of tectonic settings that can be grouped into three major types according to the different exposure levels and the nature of the crustal basement on which they were developed: Brasilides, Puntoviscana and Eastern Pampeanas.

\section{The Brasilides Tectonic Setting}

The Brasilides type can be interpreted as representing a normal continent-continent collision, where stress conditions did not persist following the deformation of the continental margin. The different tectonic elements preserved in this belt are depicted in Figure 2. Following Almeida (1984), they consist of three distinctive sequences.

The first (Fig. 2A) comprises metamorphic rocks and a magmatic arc. An older flysch-type sequence (the Cuiaba Group) is intensely tectonized and metamorphosed to greenschist facies and hosts granodioritic to granitic posttectonic plutons. The base of the flysch sequence is exposed in the northern part of the region where it consists of a granitic-gneissic complex. The sequence is parallel to the Amazonian craton border, and the granitoids are emplaced along its axis at a present distance of 80 to $100 \mathrm{~km}$ east of the old orogenic front. The whole metamorphic assemblage is thrust onto a miogeosynclinal sedimentary wedge.

The second tectonic element comprises miogeoclinal platform sequences (the Corumba Group) composed of several carbonate and clastic platforms. These were deposited during Late Proterozoic or Eocambrian times and are in tectonic contact with the metamorphic sequence. Molasse deposits constitute the third element, forming a Cambrian sequence (the Alto Paraguay Group) up to $4000 \mathrm{~m}$ thick deposited in a foredeep setting. The various facies of this sequence were deposited in a transitional marine to continental environment of increasing energy, and they culminate in redbed sequences.

Based on the provenance of these sequences, Almeida (1984) concluded that the low-grade metamorphic facies were uplifted first and that the structure migrated toward the west. Although he described the structure of the molasse deposits as a west-verging fold belt, re-study of the area suggests a complex stack of thrusts and underthrusts (the Paraguay-Araguaia fold and thrust belt, Fig. 2B) that constitutes a backthrust at the mountain front, as defined by Vann and others (1986). Although no oceanic erust has been found, the presence of the magmatic arc suggests that this orogen represents a late Precambrian, Andean-type continental are that later underwent an Eocambrian continental collision with the ensialic Alto Paraguay terrane, resulting in a major horizontal shortening. This collision resulted in the development during the Cambrian of a peripheral foredeep basin.

The collision ended with the suturing of the Amazonian craton to the Alto Paraguay ensialic terrane (Fig. 1).
Compressive stresses ended at an early stage of the collision before intercontinental subduction could develop (Aubouin 1981). Thus, the supracrustal levels are still preserved.

\section{The Puncoviscana Tectonic Setting}

The main difference between the Puncoviscana and the Brasilides type of collision is that the former is underlain not by a thick cratonic crust with a miogeoclinal prism but by a young, thin continental crust covered by a thick sedimentary flysch sequence (Fig. 2B). Available data indicate extension during late Precambrian times in this region, possibly related to the development of the continental margin along the Puncoviscana Basin (Figs. 1, 3). The association with rare mafic and ultramafic rocks is consistent with considerable attenuation of the crust (Chayle and Coira, and Omarini and Alonso, in Anon, 1987).

Recent studies in northwestern Argentina place constraints on the sedimentological characteristics, the structural pattern and the biostratigraphy of the Puncoviseana Basin (Omarini, 1983; Jezek et al., 1985; Aceñolaza and Durand,

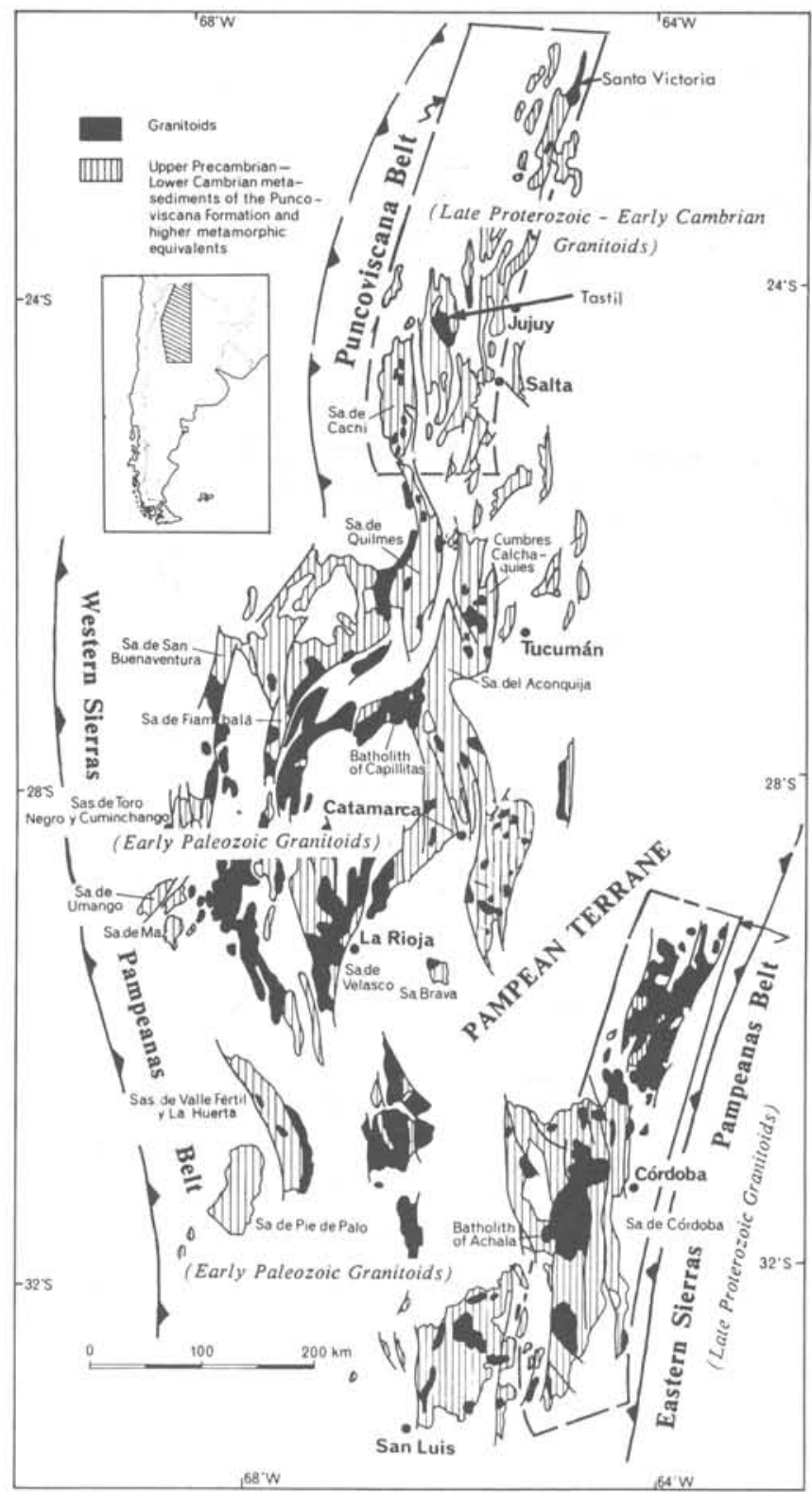

Figure 3: Sierras Pampeanas of Argentina and the main paleo-subduction zones. Modified from Ramos and others (1986); Lottner and Miller (1986). 
1985). Using this data, the basin can be interpreted as having developed on the continental rise near the base of the slope of an attenuated passive continental margin. The sediments came from the stable craton to the east (Jezek et al., ibid), and thus the basin was probably open to the proto-Pacific. Different types of turbidite sequences were developed during Vendian (Late Proterozoic) to Early Cambrian times. Deformation of the sequence makes the original thickness difficult to estimate, but it could have been several thousand metres.

The passive margin was reactivated either during latest Proterozoic or Early Cambrian times (Omarini et al., 1985; Acenolaza and Miller, 1982) with the emplacement of several batholiths such as the Santa Victoria and the Tasil, along a northeastern trending axis (Fig. 3). The exact emplacement ages of these batholiths are debatable but appear to be between 700 and $540 \mathrm{Ma}$, though the younger ages fit better with biostratigraphic controls. These granitoids are interpreted as representing a magmatic arc developed to the west of the continental slope, on either highly attenuated older or thin younger continental crust (less than 200-300 Ma old) with a thick sedimentary cover.

The deformation of the Puncoviscana Basin and the cessation of magmatism have been linked with the collision of the Pampean and Arequipa-Antofalla terranes during Early Cambrian times (Aceñolaza, 1982). The compression generated by the collision did not last as long as that in the Brasilides Belt, for several lines of evidence suggest an extensional regime developed soon after the deformation in Cambrian times (Manca et al., in Anon, 1987).

\section{Eastern Pampeanas Tectonic Type}

Although the development of the Eastern Sierras Pampeanas belt (Figs. 2C and 3) is regarded as part of the Brasiliano Cycle, time constraints suggest a slightly older magmatic and metamorphic evolution (Dalla Salda, 1987) than in the Brasilides and Puncoviscana belts. The development of this belt is constrained between about $640 \mathrm{Ma}$ ( $\mathrm{Rb} / \mathrm{Sr}$ isochron, Cingolani and Varela, 1975) and 570-580 Ma (K/Ar, Linares and Cordani, in Anon, 1976).

The Eastern Pampeanas belt appears to have formed as a result of a period of normal subduction followed by a marked continent-continent collision. This is supported by the presence of several belts of ultramafic alpine-type assemblages (disrupted belts of highly deformed ultramafic tectonites), and associated granulite facies metamorphic rocks (Villar, 1975, Gordillo, 1984) trend north-northwest along the eastern border of Sierras Pampeanas.

Important magmatic activity associated with regional metamorphism occurred during the Late Proterozoic in the eastern-most Sierras Pampeanas, suggesting that a calc-alkaline magmatic arc extended over $1,200 \mathrm{~km}$ along the belt at this time (Fig. 3). In the northern segment, magmatic activity is characterized by the intrusion of gabbros, tonalites and granodiorites with ages from 600 to $700 \mathrm{Ma}$ (K/Ar whole rock ages; Gonzalez, 1987; Lucero, 1980).

In the central and southern segments, early Paleozoic igneous activity was present, but ages of 665 to $730 \mathrm{Ma}$ ( $\mathrm{Rb} / \mathrm{Sr}$ isochrons) have been found in some diorites and granodiorites at Las Mahuidas (Fig. 1) according to Linares and others (1980) and Parica (1986). Even in the central area, where early Paleozoic activity was most intense some Proterozoic tectonomagmatic activity has been recognized by dating (Cingolani and Varela, 1975). Meta-rhyolites and meta-andesites, as well as some ortho-amphibolites have been identified in the Sal Luis region (Fig. 3; Brodtkorb et al., in Anon, 1984).

A belt of differentiated mafic and ultramafic bodies consisting of concentric zoned complexes of norite, hornblende norite, hornblende gabbros, hornblendite, orthopyroxenite, harzburgite, dunite and associated metabasalts (Kilmurray and Villar, 1981) was developed west of the magmatic arc. This is interpreted as having been formed during a period of back-arc extension in the Late Proterozoic (the Viroreo back-are belt of Fig. 1).

The Proterozoic structure of the eastern part of the Sierra Pampeanas is characterized by a high degree of deformation of metamorphic rocks along important mylonitic and cataclastic zones. Deformation in the western side of the Eastern Pampeanas is less severe and a definite westward vergence is prominent (Dalla Salda, 1987).

Assemblages in the Eastern Pampeanas decrease westwards in metamorphic grade from high-grade garnet, cordierite and hypersthene-bearing tonalitic gneisses to medium to low-grade metamorphic facies (Gordillo, 1984). These indicate a Proterozoic pressure gradient ranging from 1-6 $\mathrm{Kb}$ in the west to $5.4-6.1 \mathrm{~Kb}$ in the center to $7.1-7.4 \mathrm{~Kb}$ in the east, data that suggest differential uplift. A PT path (Fig. 4) for the Sierras de Cordoba in the Eastern Pampeanas (Fig. 3) can be constructed based on the initial conditions of Late Proterozoic metamorphism (Gordillo, ibid), the $\mathrm{P}$ and $\mathrm{T}$ of contact metamorphism produced by the emplacement of the Achala Granite during the early Paleozoic (Patino and Patino, 1987), and the younger denudation and uplift history based on cooling rates of $\mathrm{Ar}^{40} / \mathrm{Ar}^{39}$ and fission track ages on apatite (current work by Jordan and others). The data suggest an important uplift during the Brasiliano orogeny (about $15 \mathrm{~km}$ ) and minor uplifts at the end of the early Paleozoic $(3-4 \mathrm{~km})$ and during the Andean orogeny $(2-3 \mathrm{~km})$.

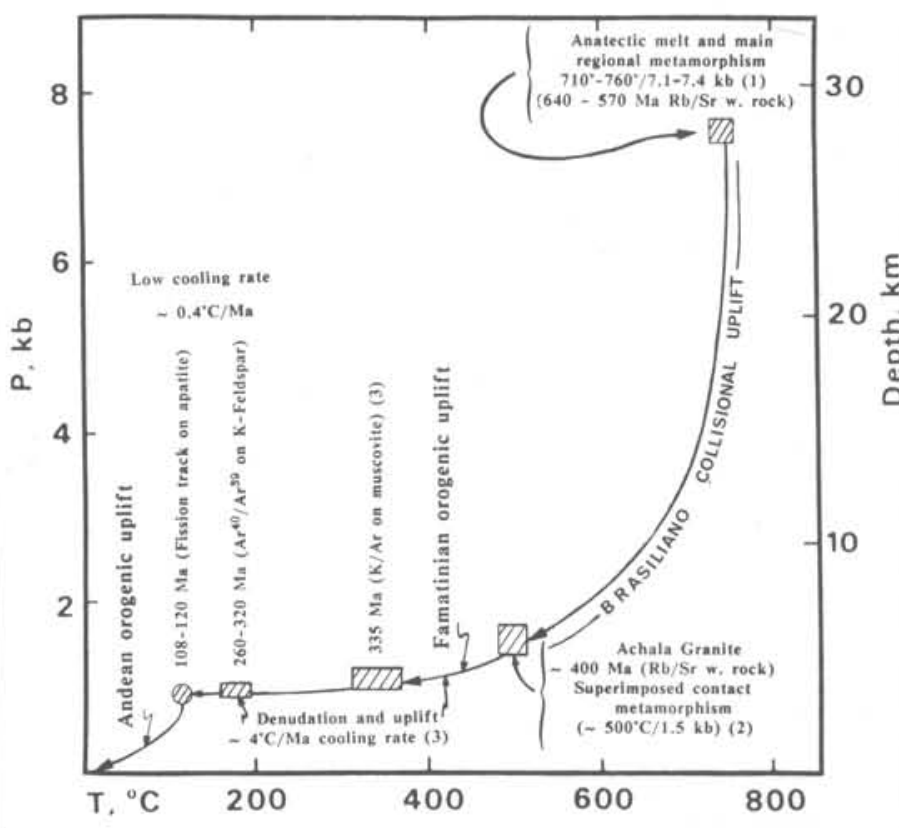

Figure 4: $\quad P-T$ path of Eastern Sierras Pampeanas. Data from (1) Gordillo (1984);(2) Patino and Patino (1987); (3) current work by Jordan and co-workers.

These relationships are consistent with a period of westdipping oceanic subduction beneath the Pampean terrane followed by an important Late Proterozoic collision between the Pampean terrane and the Rio de La Plata eraton (Fig. 2c). The compressive stress appears to have persisted longer than in the Brasilides and Puncoviseana collisions, resulting in the Pampean terrane overriding the $\mathrm{R}$ io de $\mathrm{La}$ Plata craton and the development of intense crustal shear zones and deformation. Subsequently, most of the supracrustal sequences were eroded. Some Cambro-Ordovician 
sequences, deposited east of the collision zone could represent a peripheral foreland basin, although present knowledge is insufficient to outline the geometry of the wedge that underlies the Paraná Basin.

\section{The Famatinian Orogenic Cycle}

A series of collisional episodes that occurred along the ancient southwestern border of Gondwanaland during the early Paleozoic consititute the Famatinian orogenic cycle (Aceñolaza and Tosselli, 1976; Ramos, 1988). The early Paleozoic aceretionary histories of these margins are better constrained than is the accretionary history of the Late Proterozoic. The different tectonic settings can be described with reference to two eastward traverses, one at $32^{\circ} \mathrm{S}$, the latitude of the modern Argentine Precordillera and the Sierras Pampeanas (Fig. 5) and the other at $23^{\circ}-25^{\circ} \mathrm{S}$, the latitudes of the modern Argentine Puna (Fig. 6).
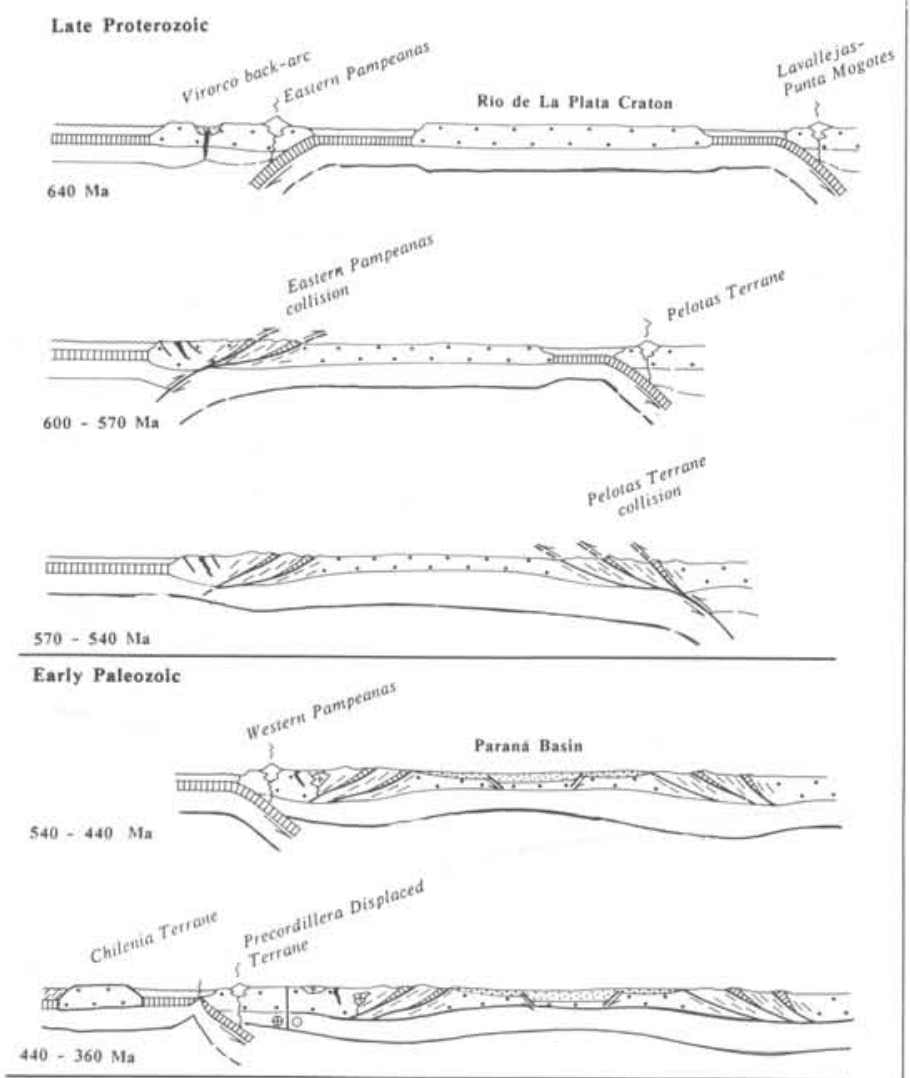

Late Paleozoic

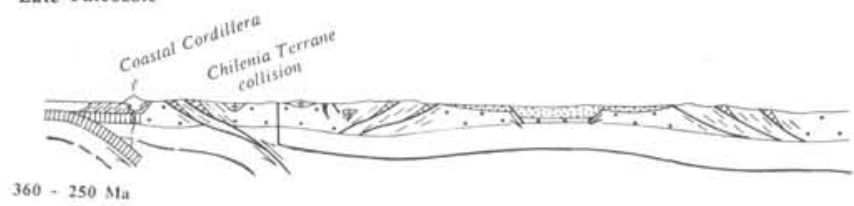

Figure 5: Schematic sections illustrating the evolution during Proterozoic and early Paleozoic of the southern traverse $\left(32^{\circ} \mathrm{S}\right)$.

\section{The $32^{\circ} \mathrm{S}$ Traverse}

An early Paleozoic magmatic are developed along the western margin of the Pampean terrane on thin, young continental crust (Ramos et al., 1986). This magmatic activity reached a maximum at the Ordovician-Silurian boundary (Ramos and Ramos, 1979; González et al., 1985), producing gabbros, quartz diorites, monzogranites and granites with

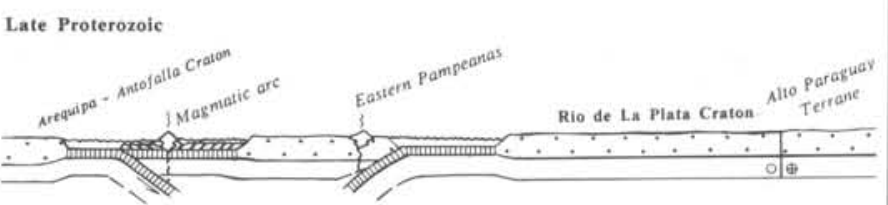

$700-600 \mathrm{Ma}$
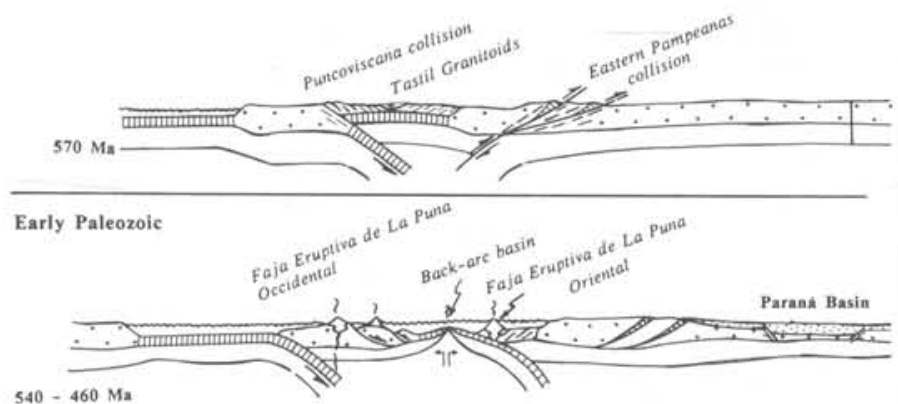

$540-460 \mathrm{Ma}$

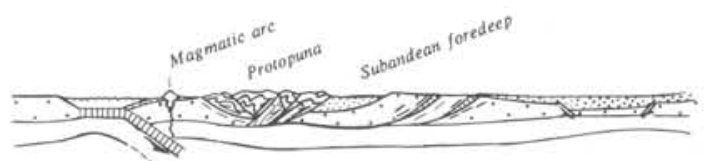

$440-360 \mathrm{Ma}$

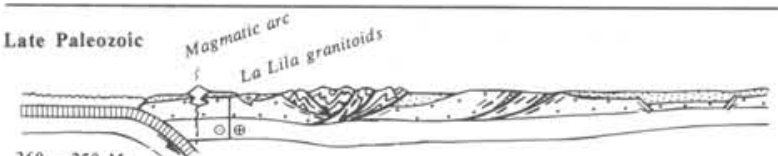

$360-250 \mathrm{Ma}$

Figure 6: Generalized profile showing the Proterozoic to early Paleozoic development of the northern traverse $\left(23-25^{\circ} \mathrm{S}\right)$.

calc-alkaline trends typical of a destructive plate margin (Rapela et al., in press). Initial $\mathrm{Sr}^{87} / \mathrm{Sr}^{86}$ ratios are low, and the rocks were probably derived from fractional crystallization of tholeiitic magmas combined with partial anatexis of the crust. Some retro-are activity, mainly of acidic composition, also occurred along the central and southern parts of the Eastern Pampeanas belt (Rapela et al., 1982; Linares et al., 1980).

During Siluro-Devonian times, magmatic activity migrated westward to the Precordillera. By the Late Devonian-Early Carboniferous, the main magmatic activity was taking place even farther westward in the Coastal Cordillera (Fig. 5; see Ramos et al., 1986)

Some ultramafic rocks on the western margin of the Sierras Pampeanas have been interpreted as lying close to a former subduction zone (Lottner and Miller, 1986). It has been suggested by Caelles (1979) that these rocks represent a suture between the Sierras Pampeanas and the Precordillera (Fig. 1). In addition, a paired metamorphic belt that exists here with a strong westward vergence could be associated with a west-dipping subduction zone (Dalla Salda and Varela, 1982). This subduction zone was apparently active until the latest Ordovician or Early Silurian, when the Precordillera displaced terrane (Baldis et al., 1984) was emplaced west of the Sierras Pampeanas, At which time, active subduction migrated to the western border of the Precordillera.

Oceanic basalts and associated mafic rocks in a belt $1000 \mathrm{~km}$ long (Kay et al., in Anon, 1984) along the western Precordillera support the existence of an oceanic basin at this time, the remnants of which were incorporated into the subduction complex zone (Haller and Ramos, in Anon, 1984). 
West of the Precordillera small isolated exposures of a Silurian carbonate platform and low-grade metamorphic rocks are the substratum for the Chilenia Terrane (Fig. 1). Farther west in Chile, this terrane is mainly composed of oceanic crust overlain by an accretionary wedge of Late Devonian and Early Carboniferous meta-sediments (Hervé et al., 1987; and see Hervé, this issue). Figure 5 summarizes the evolution along this southern traverse.

\section{The $23-25^{\circ} \mathrm{S}$ Traverse}

The composite section across the Puna indicates a complex Paleozoic history that postdated the Proterozoic accretion of the Arequipa-Antofalla craton to the Pampean terrane along the Puncoviseana belt (Fig. 6). The emplacement of mafic alkaline rocks in the Cambrian sequences (Manca et al., in Anon, 1987) east of the Puna and in the lower sequences of the eastern Faja Eruptiva de La Puna in the northern Puna (Fig. 1) suggest crustal extension. The general chemical characteristics of the alkaline mafic rocks from the lower section of the Faja Eruptiva near Abra Pampa (Koukharsky et al., 1988) are consistent with an extensional within-plate setting. Interpreted as a back-arc setting, this developed soon after the Late Proterozoic collision and lasted until the Middle Ordovician.

During the Early Cambrian to Late Ordovician a magmatic are was established along the Arequipa-Antofalla craton. The calc-alkaline plutonic rocks (e.g. the La Lila granitoids) constitute the western Faja Eruptiva de la Puna (Palma et al., 1986). Farther east, in several localities in the Puna, thick volcanic sections have been interpreted as magmatic are sequences (Coira et al., 1982, in Anon, 1987; Koukharsky et al., 1987, in Anon, 1988). Meso-silicic to acidic voleanics in the upper section of the eastern Puna at Abrapampa may also represent arc activity.

Several exposures of ophiolitic sequences along the southwestern part of the Puna suggest the development of oceanic conditions (Palma 1986; Kay et al., in Anon, 1984); these sequences were deformed and obducted during the Late Ordovician. Strong tectonism at the end of the Ordovician (the Ocloyic deformation, Coira et al., 1982) could be related to the closure of the back-are Puna Basin. A new collision of the Arequipa-Antofalla craton against the Pampean terrane and accreted volcaniclastic sequences, led to the uplift of the proto-Puna. This episode coincides with a widely recognized period of fast drift of Gondwanaland during the Late Ordovician (Van der Voo, 1988).

The Paleozoic evolution of this region ends with the westward migration of the magmatic are from Devonian to late Paleozoic times. Both forearc (Niemeyer et al., 1985) and foreland basins (Palma and Irigoyen, 1987) are recognized from this period. Many questions still remain, such as the precise location of the Cambro-Ordovician subduction zone. Was this east of the Antofalla craton with a westward polarity as claimed by Hervé and others (1987), or was it located to the west of the Antofalla craton as argued by Damm and others (1986)? Also uncertain is the precise tectonic setting of the Faja Eruptiva de La Puna Oriental, and the tectonic significance of the Ocloyic collision. Figure 6 is a working model of the early Paleozoic evolution of the northern segment.

\section{Post Famatinian Collision and Strike-slip Tectonics}

The southwestern Gondwana margin was nearly complete by the Late Devonian to Early Carboniferous. The main missing piece was the Patagonia terrane with its metamorphic cores, the Somuncura and Deseado massifs (Fig. 1), which was sutured to the Gondwana margin in the Late Permian (Ramos, 1986; Winter, 1984). Other minor exotic terranes such as that of Madre de Dios in southern Chile (Fig. 1) also accreted during the late Paleozoic to early Mesozoic (Mpodozis and Forsythe, 1983; Hervé, this issue).
Strike-slip faulting has been important in shaping the Phanerozoic Pacific margin, and a collage of displaced terranes has been identified along the coast. For example, the Pichidangui displaced terrane (Forsythe et al., 1986) was transported some $15^{\circ}$ of latitude during the Triassic, based on preliminary paleomagnetic data (Fig. 1). Several other important terranes such as the Chiloé, Chañaral and Mejillones were also actively displaced along transcurrent faults during the Phanerozoic (for a review, see Herve and Thiele, 1987). The existence of these displacements confirms the Coastal Range suture postulated by Ernst (1981) on the basis of juxtaposition of high $\mathrm{P}$-low $\mathrm{T}$ subduction complexes with high T-low $\mathrm{P}$ metamorphic rocks and the contemporaneous batholith.

\section{Concluding Remarks}

This summary of the tectonic evolution of selected areas of southern South America indicates that the development of Gondwanaland may be interpreted in terms of plate interactions, even though some of the interpretations presented are still working hypotheses. Magmatic and metamorphic belts and sedimentary basins can be explained in terms of horizontal shortening, subduction of oceanic crust, and accretion of different kinds of terranes. Gondwanaland was first formed by the agglomeration of different cratonic blocks and composite terranes during the Brasiliano Cycle, as envisaged by Porada (1979) when he postulated the collision of southwest Africa against the Rio de La Plata craton. The formation of this collage of different blocks was largely completed during the early Paleozoic, with some minor adjustments during the rest of the Phanerozoic.

The various hypothesized terrane movements are only partially supported by paleomagnetic results, and much more data on the magmatic and chronological evolution are needed for a better understanding of the tectonics. These themes will be the focus of an international cuoperative program within the framework of IGCP Project 279 "Terranes in Latin America." The next five years will undoubtedly see much excitement and debate on this complex region.

\section{Acknowledgements}

The author acknowledges Drs, José Cortés and Miguel Palma for many years of fruitful discussions in the Servicio Geológico Nacional (Argentina), various Chilean colleagues for field visits to key areas, and members of the Andes group at Cornell University. Thanks are also due to Drs. Suzanne M. Kay and Teresa Jordan for reviewing an early version of this manuscript.

Dr. V.A. Ramos is with the Geological Survey of Argentina (Av. Santa Fe 1548, P. 13, 1060 Buenos Aires, Argentina) and is also Associate Professor at the University of Buenos Aires, working mainly on Andean structure and tectonics. He is Chairman of the Andean Subcommittee of ICL, and a member of the IUGS Commission on Tectonics.

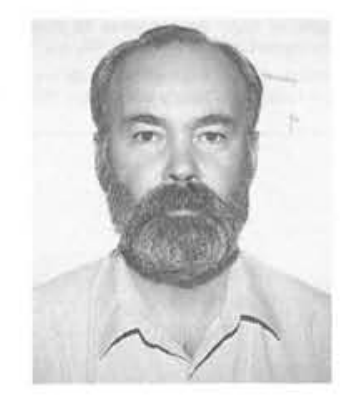


References

Aceñolaza, F.G., 1982. El sistema Ordovícico en Sudamêrica. Acta Geológica Lilloana, v. 16, по. 1, р. 77-91, Тиеити́n.

Aceñolaza, F.G. and Durand, F.R., 1985. Upper Precambrian-Lower Cambrian biota from the northwest of Argentina. Geologieal Magazine, v. 123, no. 4, p. 367-375.

Aceñolaza, F.G. and Miller, H., 1982. Barly Pateozoic orogeny in southern South America. Pre cambrian Rescareh, v. 17, no. 2, p. 133-146.

Aceñolaza, F.G. and 'roselli, A.J., 1976. Consideraciones estratigrảficas y tectônicas sobre el Paleozoico inferior del Noroeste Argentino. Memoria, lf Congreso Latinoamericano de Geología, v. 2 , D. $755-764$.

Almeida, F.F.v. de, 1964. Ceologir do eentro-oeste matogrossensc. Departamento Nacional Produção Mineral, isotctim 215, p. 1-137, Rio de Janeito.

Almeida, F.F.M. de, 1984. Provineis Tocantins, Setor Sudoeste. In: Almeida, F.F. N. de and Hasui, Y. (eds), O Précarnbriano do Brasil, p. 265-281, São Paulo.

Almeida, F.F.M. de, Hasui, Y. and l3rito Neves, B.B., 1976. The Upper Precambrian of South America. Universidade de São Paulo, Instituto de Geociêneias, Boletim, y, 7 , p. 45-80, São Paulo. Anhocusser, C.R., Mason, R., Viljoen, J. and Viljoen, R.P., 1969. A reappraisal of some aspects Precambrian shield geology. Geological Society of America, Bulletin, v. 80, no. 11 , p. 2175-2200. Anon, 1976. Actas VI Congreso Geológico Argentino, Bahia Blanca. Asociación Gcológica Argentins, v. 2 .

Anon, 1984. Actas $1 \times$ Congreso Geológico Argentino, Bariloche. Asociación Geol. Argentina, v.2 Anon., 1987. Actas X Congreso Geológico Argentino, Tucumăn. Asociación Geol. Argentina, v.4 Aubouin, J., 1981. About mountain building. Geological society of China, Hemoir, v. 4, p. 33-53, Taiพลn.

I3aldis, B.A., Beresi, M.S., Bordonaro, O. and Vaca, A., 1984. The Argentine Precordillera as a key to Andean strueture. Lipisodes, v. 7, no. 3, p. J4-19,

Bernasconi, A., 1987. The major Precambrian terranes of eastern South Americt: a study of their regional and chronological evolution. Precambriqn Researeh, v. 37, no. 2, p. 107-124.

Caelles, J.C., 1979 . The geological evolution of the Siorras Pampernas massif, La Rioja and Cata marea provinees, Amentina. Queen's University, Unpublished Jh.lJ. Thesis, Kingston, Canada, p. $1-453$

Cingolani, C.A. and Varela, R., 1975. Ceocronologin Rubidio-listroncio de rocas igneas y meta márícas de las Sierras Chica y Grande de Córdoba, Repúbijer Argentina. Actas 11 Congreso Lberoamericano de Geología liconómica, v. 1, p, y-35, Buenos Aires.

Coira, B.L., Davidson, J.D., Mpodozis, C. and Ramos, V.A., 1982. Tectonic and magmatic evolution of the Andes of northern Argentina and Chile. Farth-Science Reviews, v. 18 no- 3-4, p. $30,3-332$.

Cordani, U.G. and Brito Neves, B.H3., 1982. The geologic evolution of South America during the Arehean and Larly Proterozoic. Revista Brasileira de Geociências, v. 12, no. 1-3, p. 78-88, são J'oulo.

Dalla Salda, L., 1987. Basement tectonics of the southern Pampean Ranges. T'ectonies, v, 6, no. 3 , p. $249-260$.

Dalla Salda, L. and Varela, R, 1982. La estructura del basamento del tercio sur de la Sierra de Pie de Palo, Provincia do San Juan, Argentina. Actas V Congroso Latinoamericano de Geología, v, 1, p. $45 \div-468$, Buenos Aires.

Damm, K.W., P'jehowiak, S. and Todt, W., 1986. Geochemie, Petrologie und Geochronologie der Plutonite und des Metamophen Grundgebirges in Nordchile. Berliner Geowissenschaftliche Abhandiungen, Reihe $\Lambda, v, 6 \hbar, p .73-146$, Berlin.

Linst, W.G., 1981. Petrotectonie settings of glaucophane sehist belts and some implications for Triwan. Geological Socicty of (Ching, Memoir, v. 4, p. 229-267, Taiwan.

Forsythe, R.U., Kent, D.V., Mpodozis, C. and Davidson, J., I986. Paleomagnetism of P'ermian and Triassic Rocks, Central Chilean Andes. In: Mckienzie, G.1). (ed.), Gondwana Six: Structure, Pectonies,
p. $241-252$.

Fulfaro, V.J., Saad, A.K., Santos, M.V. and Vianna, R.13., 1982. Compartimentação e evolução tectonica da Bacia do Paraná. Revista lsrasilejra de Geociências, v. 12, no. 4, p. 590-61 1, São

González, R., 1987. Lstudio del basamento metamórfico existente en el sector septentrional de Sierra Norte de Córdoba (Sierra de la lligueritzs, Sauce Puncu y Sun Pedro Nortel y alrededore

de Cruz del tie. CAPlCa. In forme del Comitë Nacional de Argentina, Buenos Aires, p. 39-4l.

Conzález, K., Cabrera, M.A., Castellote, P., Omil, M., Bortolitti, P., Moyano, H. and Ojeda, J., 1985. Hisquematización de la ubicacion espacial y temporal de la eruptividad en Sierras l'ampeanas Noroceidentale
p. $138-150$

Gordillo, C.E., 1984. Wigmatitus cordjeríticas de la Sierry de Córdoba; condiciones físicas de mig-

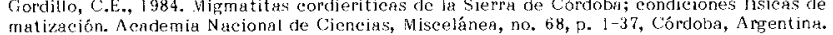

Harrington, II.J., 1975. South America. In: Fairbridge, K.W. (ed.), The Encyclopedia of World Regional Geology, Part l. Dowden, Ilutehinson, Ross, Penrisylvania, p. 456-465.

Ilervé, F. Ciodoy, E., Parada, M., Ramos, V.A., Rapela, C., Vpodozis, C. and I)avidson, J., 1987. A genergi vicw of the Chilean-Arrentine Andes, with emphais on their early history. In: J. Monger
and $J$. Francheteau (eds.), Circum-Pacific Orogenic Betts and Evolution of the Pacific Deean Basin. Americun Geophysieal Union Geodynamies Series, v. 18, p. 97-113.

Jezek, P., Willner, A.P., Aceñolaza, F.(i. and Miller, 1H., 1985. The Puncoviscana trough - a linge basin of Lute Preeumbrian to Early Cambrian age on the Pacific edge of the lirazilian shield. Geologische Rundschau, v. 74 , no. 3, p. 573-584.

Keidel, J., 1917. La geología de las Sicrras de ta provincia de Buenos Aires y sus relaciones con les montañas del Cabo y los Andes. Ministerio Agricultura, Anales, Geologła, v, 9, no. 3, Buenos Aircs. Kilmurray, J.o. and Villar, L.M., 1981. El basamento de la Sierra de San Luis y su petrología. In:
Geología y Recursos Naturales de la Provincia de San Luis. Relatorio, VIII Congreso Geológico Argentino, San Luis, p. 33-54, Buenos Aires.

Koukharsky, M.L., Coira, B.L., Barber, E., and Hanning, M., 1988. Genchíruica de voleanitas Drdovicias de la Pune Argentina y sus impliegciones tectónicas. Actas del v Congreso Geológico Chileno, v. 3 , p $1137-152$.

Linares, E., Llambias, E.J. and Latoree, C.O., 1980. Ceología de la Provincia de La Pampa, República Argentina y Gcocronología de sus cocas metamórficas y eruptivas. Revista, Asociación Gicológica Argentina, v. 35, no. 1, p. 87-146, Buenos Aires.

Linares, E., Cagnoni, M., Campo, M. do and Ostera, H., 1985. Ceocronologír de las rocas metamórficas y eruptivas de la provincia del Neuquén y del noroes
República Argentina. Comunicaciones, v. 35 , p. 129-136, Santiago.

Lottner, U.S. and Miller, H., 1986. The Sierra de Ancasti as an oxample of the strueturatily Lether, \%entralblat für Geologie und Pa! öontologie, Part 1, no. 9-10, p. 1269-1281, Stuttgart.

Lucero, M.II.N., 1980. Sierras Pampeanas del Norte de Córdoba, Sur de Santiago del listero, borde oriental de Catamarca y ángulo sudeste de Tucumán. Segundo simposio de Coologła Regional Argentina. Academia Nacional de Ciencias, v, 1, p. 293-347, Cordoba.

Mpodozis, C. and Forsythe, R., 1983. Stratigraphy and geochemistry of acereted fragments of the ancestral Pacific floor in southern South America: Palaeogeography, Palacoelimatology and P\&laeoecology, v. 41, no. 1-2, D. 103-1 24 .

Niemeyer, R.H., Urzúa, A.F., Aceñolaza, r.,.. and González, C.R., 1985. Progresos recientes en el conocimiento del Paleozoico de
v. 1, p. $410-438$, Antofugasta.

Omarini, R.Il., I983. Caracterización litológica, diferenciación y génesis de lat Formación Puncoviscana entre el valle de Lerma y la Faja Eruptiva de la Puna. Universidad Nacional de Salta, Unpublished Ph. l). Thesis, Salta, p. 1-202.

Omarini, R.ll., Aparicio, A., Parica, C., Pichowiak, S., Gareia, L., Damm, K.W., Viramonte, J.G., Salfity, J.A. and Alonso, R.N., 1985. New geochronologieal data shed light upon Precambrian age
of Puncoviscona Formation, northwestern Argentina. Comunieaciones, v. 35, p. 181-184, Santiago, Chile.

Pacci, D., Munizaga, F., Hervé, F., Kawashita, K. and Cordani, U., 1980. Acerea de la edad Rb-Sr Revamba Geológica de Chile, no. 11 , p. 43-50, Santiago.

Palma, M.A., 1986. Geologia del bloque paleozoico de la Sierra de Quebrada Ionda, Puna Catnmarqueñ.. Servicio Gicológico Nacional (inédito), Buenos Aires.

Palma, M.A. and Irigoyen, M.V., 1987. Los estratos de Botijuela en la Puna Catimargueñ. Actas $X$ Congreso Geológieo Argentino, Tucumán, v. 2, p. 139-142, Buenos Aires.

Palma, MA.A., Parica, P.D. and Ramos, V.A., 1986. El Granito Archibarea: su edad y significado tectónico. Revista, Asociación Geológica Argentina, v. 41, no. 3-4, p. 414-419, Buenos Aires.

Parica, P.U., 1986. Petrología y geocronología del sector central de la Sierra de Loneo Vaca, Ju Pampa. Revista, Asociación Geológica Argentina, v. 4 I, no, 3-4, p. 270-289, Buenos Aires.

Patiño, M.G. de and Patiño Douce, A.E., 1987. Petrología y petrogénesis del batolito to Achala, provincia de Córdobar a la luz de la evidencia de campo. Revista, Asociación Geológiez Argentina, provineia de Cordoba, a la luz de la evides
v. 42 , no. $1-2$, p. $148-152$, Buenos Aires.

Porada, H., 1979. The Damara-Riveira orogen of the Pan African-3rasiliano cycle in Namibia (Southwest Africa) and Brazil as intepreted in terms of continental collision. T'ectonophysics v. 57 , no. $2-4$, p. $237-265$

Ramos, k.19. and Rumos, V.A., I979. Los ciclos magmáticos de la Repútblica Argentina. Actas VII Congreso Gcológico Argentino, Neuquén, v. 1, p. $771-786$, 13uenos Aires.

kamos, V.A., 1986. Tectonostratigraphy, as applied to analysis of South African Phanerozoic Basins by H. de lis R. Winter, discussion and reply. Transactions of the Gologieal Society of South $\Lambda$ frica, v. 89 , no. 3 , p. $427-429$.

Ramos, V.A., 1988. The Tectonies of the Central Andes, $30^{\circ}$ to $33^{\circ} \mathrm{S}$ latitude. In: Clark, $\mathrm{S}$. and Burchfiel, D. (eds), Processes in Continental Lithospheric Deformetion Geological Society of America, Special Paper 218 , p. $31-54$

ramos, V.A., Jordan, T.K., Allmendinger, R.W., Mpodozis, C., Kay, S., Cortés, J.M. and Palma, M.A., 1986. Prieozoic terranes of the Central Argentine-Chilean Andes Fectonics, v. 5, no. 6, p. $855-880$.

Rapeta, C.W., Heaman, L.W. and McNutt, R.11., 1982. Rb/Sr geochronology of granitoid rocks from the Pampean Ranges, Argentina. Journal of Geology, v. 90, p. $574-582$.

Rapela, C.W., Toselli, A., Heaman, L. and Saavedra, J., in press. Granite plutonism of the Sierras Pampeanas: an inner Cordilleran Paleozoic are in the Southern Andes. Geological Society America Memoir.

Russo, A., Ferello, A. and Chetıli, G., 1979. Llanura Chaco pampeana. Segundo Simposio de Geología Regionál Argentina l, p. 139-183, Córdoba.

Shackleton, R.M., Rics, A.C., Coward, M.P. and Cobbold, P.R., 1979. Structure, metamorphism and geochronology of the Aregujpa thassif of constal Peru. Journal Geological Socicty of London,
v. 136 , Part 2, p. 195-214.

Vann, L.R., Graham, R.H. and Hayward, A.B., 1986. The structure of mountain fronts. Journal of Structurai Geology, v. 8 , no. 3-4, p. 215-227.

Van der Voo, R., 1988. Paleozoic paleogeography of North America, Condwana, and intervening displaced terranes: comparisons of pateomagnetism with paleoclimatology and biogeographica patterns. Geological Societ y America, Bullet in, v. 100, no. 3, p. 311-324.

Villar, L. 3., 1975. Las fajas y ostras manifestaciones ułtrabásicas de la República Argentina y su significado metalógenético. Actas II Congreso lberonmericano de Geología Económica, v, 3, p. $135-156$, Buenos Aires.

Winter, 1f. de la R., 1984. Tectonostratigraphy, as applied to analysis of South African Phanerozoic basins. Transactions of the Geological Society of South Africa, v. 87, no. 2, p. $169-179$. 